\title{
HUBUNGAN KEPEMIMPINAN KEPALA SEKOLAH DAN SIKAP GURU TERHADAP PEKERJAAN DENGAN KOMPETENSI PROFESIONAL GURU
}

\author{
(The Relationship of Principal Leadership and Teachers' Attitude to their Work \\ with the Teacher's Professional Competence) \\ SONEDI
}

\author{
Program Studi Pendidikan Ekonomi Fakultas Keguruan dan IImu Pendidikan \\ Universitas Muhammadiyah Palangkaraya \\ JI. RTA Milono Km.1,5 Palangka Raya, Kalimantan Tengah 73111
}

e-mail : sonedi.lilik@gmail.com

\begin{abstract}
The aim of this study; 1). to know the relationship of the principal leadership to the teacher's professional competence at Junior High School of Palangka Raya city; 2). to know the relationship of teachers' attitudes to their work, and 3). to know the relationship of principal leadership, teachers' attitudes to their work with the teachers' professional competence at the private Junior High School of Palangka Raya city.

These results showed that: 1) there is a significant relationship with the leadership of the principal with the economic teachers' professional competence at the private Junior High School of Palangka Raya city. It means that the higher of the level of the principal leadership, it will be followed by the higher of the professional competence of the teachers. Conversely, the lower of the leadership of the principal, the professional competence of the teachers will be lower too; 2) there is a significant relationship of the teachers' attitude to their work with the economic teachers' professional competence at private Junior High Shool in Palangka Raya city. It means that the higher of positive teachers' attitude to work, the professional competency of the teachers will be higher, and vice versa; 3) there is a significant relationship of the principal leadership and teachers' attitudes to their work with economic teachers' professional competence at the private Junior High School in Palangka Raya city.
\end{abstract}

Keywords: leadership of the principal, teachers' attitudes to their work and teachers' professional competence

\begin{abstract}
ABSTRAK
Penelitian ini bertujuan: 1). untuk mengetahui hubungan kepemimpinan kepala sekolah dengan kompetensi professional guru di SMP Negeri Kota Palangka Raya; 2). untuk mengetahui hubungan sikap guru terhadap pekerjaan, dan 3). untuk mengetahui hubungan kepemimpinan kepala sekolah dan sikap guru terhadap pekerjaan dengan kompetensi professional guru di SMP Negeri Kota Palangka Raya.

Hasil penelitian ini menunjukan bahwa: 1) ada hubungan yang signifikan kepemimpinan kepala sekolah dengan kompetensi profesional guru ekonomi di SMP Negeri Kota Palangka Raya. Hal ini berarti bahwa semakin tinggi tingkat kepemimpinan kepala sekolah, maka akan diikuti semakin tinggi pula kompetensi professional guru. Sebaliknya semakin rendah kepemimpinan kepala sekolah, akan semakin rendah pula kompetensi profesiona guru; 2) ada hubungan yang signifikan sikap guru terhadap pekerjaan dengan kompetensi professional guru ekonomi di SMP Negeri Kota Palangka Raya. Hal ini berarti bahwa semakin tinggi sikap positif guru terhadap pekerjaannya, akan semakin tinggi pula kompetensi professional guru, demikian juga sebaliknya; 3) ada hubungan yang signifikan kepemimpinan kepala sekolah dan sikap guru terhadap pekerjaan dengan kompetensi professional guru ekonomi di SMP Negeri Kota Palangka Raya.
\end{abstract}

Kata kunci: kepemimpinan kepala sekolah, sikap guru terhadap pekerjaan dan kompetensi professional guru 


\section{PENDAHULUAN}

Pendidikan merupakan faktor utama dalam pembentukkan pribadi manusia. Pendidikan sangat berperan dalam membentuk baik atau buruknya pribadi manusia menurut ukuran normatif. Menyadari akan hal tersebut, pemerintah sangat serius menangani bidang pendidikan, sebab dengan sistem pendidikan yang baik diharapkan muncul generasi penerus bangsa yang berkualitas dan mampu menyesuaikan diri untuk hidup bermasyarakat, berbangsa dan bernegara.

Reformasi pendidikan merupakan respon terhadap perkembangan tuntutan global sebagai suatu upaya untuk mengadaptasikan sistem pendidikan yang mampu mengembangkan sumber daya manusia untuk memenuhi tuntutan zaman yang sedang berkembang. Melalui reformasi pendidikan, pendidikan harus berwawasan masa depan yang memberikan jaminan bagi perwujudan hak-hak azasi manusia untuk mengembangkan seluruh potensi dan prestasinya secara optimal guna kesejahteraan hidup di masa depan.

Guru adalah salah satu unsur manusia dalam proses pendidikan (Djamarah, 2012). Dalam proses pendidikan di sekolah, guru memegang tugas ganda yaitu sebagai pengajar dan pendidik. Sebagai pengajar guru bertugas menuangkan sejumlah bahan pelajaran ke dalam otak anak didik, sedangkan sebagai pendidik guru bertugas membimbing dan membina anak didik agar menjadi manusia susila yang cakap, aktif, kreatif, dan mandiri. Djamarah (2012) berpendapat bahwa mengajar maupun mendidik merupakan tugas dan tanggung jawab guru sebagai tenaga profesional. Oleh sebab itu, tugas yang berat dari seorang guru ini pada dasarnya hanya dapat dilaksanakan oleh guru yang memiliki kompetensi profesional yang tinggi.

Guru memegang peranan sentral dalam proses belajar mengajar, untuk itu mutu pendidikan di suatu sekolah sangat ditentukan oleh kemampuan yang dimiliki seorang guru dalam menjalankan tugasnya. Menurut Aqib (2013) guru adalah faktor penentu bagi keberhasilan pendidikan di sekolah, karena guru merupakan sentral serta sumber kegiatan belajar mengajar. Lebih lanjut dinyatakan bahwa guru merupakan komponen yang berpengaruh dalam peningkatan mutu pendidikan di sekolah. Hal ini menunjukkan bahwa kemampuan atau kompetensi profesional dari seorang guru sangat menentukan mutu pendidikan.

Berdasarkan hasil uji kompetensi guru pada tahun 2015 bidang pedagogik, rata-rata kompetensi guru di Indonesia hanya $56,69 \%$. Angka ini masih relatif jauh di bawah standar nilai kompetensi minimal yang diharapkan yaitu $75 \%$. Berdasarkah hasil penelitian yang dilakukan oleh John Hattie ada beberapa faktor yang mempengaruhi pristasi belajar peserta didik antara lain: karakteristik siswa (49\%), guru $(30 \%)$ dan lain-lain (21\%) (Pikiran Rakyat: 4 Mei 2016).

Tingkat kompetensi profesional guru pada dasarnya dipengaruhi oleh faktor dari dalam guru itu sendiri yaitu bagaimana guru bersikap terhadap pekerjaan yang diemban. Sedangkan faktor luar yang diprediksi berpengaruh terhadap kompetensi profesional seorang guru yaitu kepemimpinan kepala sekolah, karena kepala sekolah merupakan pemimpin guru di sekolah.

Sikap manusia diidentifikasi oleh para ahli dalam berbagai versi. Sikap guru terhadap pekerjaan merupakan keyakinan seorang guru 
mengenai pekerjaan yang diembannya, yang disertai adanya perasaan tertentu, dan memberikan dasar kepada guru tersebut untuk membuat respons atau berperilaku dalam cara tertentu sesuai pilihannya. Sikap guru terhadap pekerjaan mempengaruhi tindakan guru tersebut dalam menjalankan aktivitas kerjanya. Bilamana seorang guru memiliki sikap positif terhadap pekerjaannya, maka sudah barang tentu guru akan menjalankan fungsi dan kedudukannya sebagai tenaga pengajar dan pendidik di sekolah dengan penuh rasa tanggung jawab. Demikian pula sebaliknya seorang guru yang memiliki sikap negatif terhadap pekerjaannya, pastilah dia hanya menjalankan fungsi dan kedudukannya sebatas rutinitas belaka. Untuk itu amatlah perlu kiranya ditanamkan sikap positif guru terhadap pekerjaan, mengingat peran guru dalam lingkungan pendidikan dalam hal ini sekolah amatlah sentral.

Sekolah sebagai organisasi, di dalamnya terhimpun unsur-unsur yang masing-masing baik secara perseorangan maupun kelompok melakukan hubungan keja sama untuk mencapai tujuan. Unsur-unsur yang dimaksud, tidak lain adalah sumber daya manusia yang terdiri dari kepala sekolah, guru-guru, staf, peserta didik atau siswa, dan orang tua siswa. Tanpa mengenyampingkan peran dari unsur-unsur lain dari organisasi sekolah, kepala sekolah dan guru merupakan personil intern yang sangat berperan penting dalam menentukan keberhasilan pendidikan di sekolah.

Keberhasilan suatu sekolah pada hakikatnya terletak pada efisiensi dan efektivitas penampilan seorang kepala sekolah (Wahjosumidjo, 2015). Sedangkan sekolah sebagai lembaga pendidikan bertugas menyelenggarakan proses pendidikan dan proses belajar mengajar dalam usaha untuk mencerdaskan kehidupan bangsa. Dalam hal ini kepala sekolah sebagai seseorang yang diberi tugas untuk memimpin sekolah, kepala sekolah bertanggung jawab atas tercapainya tujuan sekolah. Kepala sekolah diharapkan menjadi pemimpin dan inovator di sekolah. Oleh sebab itu, kualitas kepemimpinan kepala sekolah adalah signifikan bagi keberhasilan sekolah.

Wahjosumidjo (2015: 431) mengemukakan bahwa kepemimpinan kepala sekolah adalah prestasi atau sumbangan yang diberikan oleh kepemimpinan seorang kepala sekolah, baik secara kualitatif maupun kuantitatif yang terukur dalam rangka membantu tercapainya tujuan sekolah. Penampilan kepemimpinan kepala sekolah ditentukan oleh faktor kewibawaan, sifat dan keterampilan, perilaku maupun fleksibilitas pemimpin. Selanjutnya Wahjosumidjo (2015), agar fungsi kepemimpinan kepala sekolah berhasil memberdayakan segala sumber daya sekolah untuk mencapai tujuan sesuai dengan situasi, diperlukan seorang kepala sekolah yang memiliki kemampuan profesional yaitu: kepribadian, keahlian dasar, pengalaman, pelatihan dan pengetahuan profesional, serta kompetensi administrasi dan pengawasan.

Kemampuan profesional kepala sekolah sebagai pemimpin pendidikan yaitu bertanggung jawab dalam menciptakan suatu situasi belajar mengajar yang kondusif, sehingga guru-guru dapat melaksanakan pembelajaran dengan baik dan peserta didik dapat belajar dengan tenang. Disamping itu kepala sekolah dituntut untuk dapat bekerja sama dengan bawahannya, dalam hal ini guru. 
Berdasarkan uraian di atas, menunjukkkan bahwa kepemimpinan kepala sekolah dan sikap guru terhadap pekerjaan merupakan faktor yang cukup menentukan tingkat kompetensi profesional guru. Sehinga dapat diduga bahwa masih rendahnya kompetensi profesional guru dalam hal ini guru Ekonomi SMP Negeri di Kota Palangka Raya. Kompetensi profesional guru itu sendiri yang rendah, kepemimpinan kepala sekolah yang kurang efektif dan sikap guru yang negatif terhadap pekerjaannya.

Berdasarkan uraian di atas, maka permasalahan dalam penelitian ini adalah sebagai berikut: (1) apakah ada hubungan kepemimpinan kepala sekolah dengan kompetensi guru ekonomi di SMP Negeri Kota Palangka Raya?; (2) apakah ada hubungan sikap guru terhadap pekerjaan dengan kompetensi professional guru ekonomi di SMP Negeri Kota Palangka Raya? (3) apakah ada hubungan kepemimpinan kepala sekolah dan sikap guru terhasap pekerjaan dengan kompetensi guru ekonomi di SMP Negeri Kota Palangka Raya?. Penelitian ini bertujuan untuk mengetahui hubungan kepemimpinan kepala sekolah, sikap guru terhadap pekerjaan dengan kompetensi profesional guru ekonomi SMP Negeri Kota Palangka Raya.

$\begin{array}{cccc}\text { Moqvist (dalam } & \text { Sonedi, } & \text { 2011) } \\ \text { mengemukakan bahwa kompetensi } & \text { telah }\end{array}$ digambarkan dari sudut keadaan yang nyata yang berkenaan dengan individu dan pekerjaan. Menurut Littrell (1984: 310) kompetensi adalah kekuatan mental dan fisik untuk melakukan tugas atau keterampilan yang dipelajari melalui latihan dan praktik. Sedangkan menurut Kenezevich (1984: 17), kompetensi adalah kemampuankemampuan untuk mencapai tujuan organisasi.
Kemampuan-kemampuan di sini merupakan hasil dari penggabungan dari kemampuan yang banyak jenisnya, dapat berupa pengetahuan, keterampilan, kepemimpinan, kecerdasan, dan lain-lain yang dimiliki seseorang untuk mencapai tujuan organisasi.

Sonedi (2011), mengemukakan kompetensi pada dasarnya merupakan gambaran tentang apa yang seyogyanya dapat dilakukan (be able to do) seseorang dalam suatu pekerjaan, berupa kegiatan, perilaku dan hasil yang seyogyanya dapat ditampilkan atau ditunjukkan. Agar dapat melakukan (be able to do) sesuatu dalam pekerjaannya, tentu saja seseorang harus memiliki kemampuan (ability) dalam bentuk pengetahuan (knowledge), sikap (attitude) dan keterampilan (skil) yang sesuai dengan bidang pekerjaannya.

Istilah profesional guru bukan merupakan istilah asing dalam dunia pendidikan. Secara sederhana, profesional berasal dari kata profesi yang berarti jabatan. Orang yang profesional adalah orang yang mampu melaksanakan tugas jabatannya secara mumpuni, baik secara konseptual maupun aplikatif. Guru yang profesional adalah guru yang memiliki kemampuan yang mumpuni dalam melaksanakan tugas jabatan guru (Sonedi, 2011).

Profesi diukur berdasarkan kepentingan dan tingkat kesulitan yang dimiliki. Dalam dunia keprofesian dikenal terminologi kualifikasi profesi yaitu: profesi, semi profesi, terampil, tidak terampil, dan quasi profesi. Gilley dan Eggland (dalam Karsidi, 2005) mendefinisikan profesi sebagai bidang usaha manusia berdasarkan pengetahuan, dimana keahlian dan pengalaman pelakunya diperlukan masyarakat. 
Mengacu kepada uraian di atas, maka kompetensi profesional guru dapat diartikan sebagai kemampuan seorang guru dalam melaksanakan tugas profesi keguruan dengan penuh tanggung jawab dan dedikasi tinggi dengan sarana penunjang berupa bekal pengetahuan yang dimilikinya. Kompetensi merupakan perilaku yang irasional untuk mencapai tujuan yang dipersyaratkan sesuai dengan kondisi yang dipersyaratkan pula. Kompetensi sangat diperlukan untuk mengembangkan kualitas dan aktivitas tenaga kependidikan.

Ibrahim (2014) berpendapat bahwa inovasi adalah suatu gagasan, teknik-teknik atau benda yang disadari dan diterima oleh seseorang atau kelompok untuk diadopsi. Inovasi sebagai sesuatu gagasan atau ide baru yang diterapkan untuk membuat atau mengembangkan sebuah produk, proses atau jasa. Sedangkan Sudjana (2010) mengemukakan empat kompetensi guru: (1) mempunyai pengetahuan tentang belajar dan tingkah laku manusia, (2) mempunyai pengetahuan dan menguasai bidang studi yang dibinanya, (3) mempunyai sikap yang tepat tentang diri sendiri, sekolah, teman sejawat, dan bidang studi yang dibinanya, dan (4) mempunyai keterampilan teknik mengajar.

Berdasarkan Undang-undang Guru dan Dosen bahwa tenaga kependidikan harus memiliki kompetensi pribadi, profesional, sosial. Uraian dari ketiga kompetensi tersebut adalah sebagai berikut: (1) kompetensi pribadi seorang guru meliputi; memiliki pengetahuan tentang adat istiadat baik sosial maupun agama, memiliki pengetahuan budaya dan tradisi, memiliki pengetahuan tentang inti demokrasi, memiliki apresiasi dan kesadaran sosial, memiliki pengetahuan tentang estetika, memiliki sikap yang benar terhadap pengetahuan dan pekerjaan, dan setia terhadap harkat dan martabat manusia, (2) kompetensi profesional meliputi; mengerti dan dapat menerapkan landasan kependidikan filosofis maupun psikologis, mengerti dan dapat menerapkan teori belajar sesuai dengan ingkat perkembangan perilaku peserta didik, mampu menangani mata pelajaran atau bidang studi yang ditugaskan kepadanya, mengerti dan dapat menerapkan metode mengajar yang sesuai, mampu menggunakan alat dan fasilitas belajar, mampu mengorganisasikan dan melaksanakan program pengajaran, mampu melaksanakan evaluasi belajar, dan mampu menumbuhkan kepribadian peserta didik, (3) kompetensi sosial guru meliputi; kemampuan berkomunikasi dengan masyarakat, bergaul dan melayani masyarakat dengan baik, mendorong dan menunjang kreativitas masyarakat, menjaga emosi dan perilaku yang kurang baik, dan menempatkan diri sesuai dengan tugas dan fungsinya baik di sekolah maupun di lingkungan masyarakat.

Berdasarkan uraian di atas, konsep kompetensi profesional guru dalam penelitian ini dapat diartikan sebagai kemampuan dasar melaksanakan tugas keguruan yang dapat dilihat dari kemampuan merencanakan program belajar mengajar, kemampuan melaksanakan atau mengelola proses belajar mengajar, dan kemampuan menilai proses belajar mengajar.

Kepala sekolah tersusun dari dua kata yaitu "kepala" yang dapat diarti kan ketua atau pemimpin dalam suatu organisasi atau sebuah lembaga, dan "sekolah" yaitu sebuah lembaga di mana menjadi tempat menerima dan member pelajaran. Secara sederhana kepala sekolah dapat 
didefinisikan sebagai seseorang tenaga fungsional guru yang diberi tugas untuk memimpin suatu sekolah dimana diselenggarakan proses belajar mengajar, atau tempat di mana terjadinya interaksi antara guru yang memberi pelajaran dan murid yang menerima pelajaran.

Kepala sekolah dilukiskan sebagai orang yang memiliki harapan tinggi bagi para staf dan para siswa. "Kepala sekolah adalah mereka yang banyak mengetahui tugas-tugas mereka dan mereka yang menentukan irama bagi sekolah mereka" (Lipham, 1985). Urian tersebut menunjukkan pentingnya peranan kepala sekolah dalam menggerakkan kehidupan sekolah guna mecapai tujuan.

Kepemimpinan adalah bagian penting manjemen, tetapi tidak sama dengan manajemen. Kepemimpinan merupakan kemampuan yang dipunyai seseorang untuk mempengaruhi orang lain agar bekerja mencapai tujuan dan sasaran. Manajemen mencakup kepemimpinan tetapi juga mencakup fungsi-fungsi lainnya seperti perencanaan, penorganisasian, pengawasan dan evaluasi (Handoko, 2012). Lebih lanjut Handoko (2012) mengungkapkan kepemimpinan atau leadership dalam pengertian umum menunjukkan suatu proses kegiatan dalam hal memimpin, membimbing, pengontrol perilaku, perasaan serta tingkah laku terhadap orang lain yang ada di bawah pengawasannya. Disinilah peranan kepemimpinan berpengaruh besar dalam pembentukan perilaku bawahan. menurut Handoko (2012) kepemimpinan merupakan kemampuan seseorang untuk mempengaruhi orang lain agar mencapai tujuan dan sasaran.
George R.Terry, menjelaskan bahwa leadership is the activit of influencing people to strive willingly for group objectives. Pendapat lain dari Stoner, kepemimpinan adalah suatu proses pengarahan dan pemberian pengaruh pada kegiatan-kegiatan dari sekelompok anggota yang saling berhubungan tugasnya. Sedangkan Harold Koontz and Cyril O'Donnell, menjelaskan bahwa state that leadership is influencing people to follow in the achivement of a common goal.

Handbook of Leadership, memberikan definisi kepemimpinan sebagai“suatu interaksi antar anggota suatu kelompok". Pemimpin merupakan agen perubahan, orang yang perilakunya akan lebih memengaruhi orang lain daripada perilaku orang lain yang memengaruhi mereka. Kepemimpinan timbul ketika satu anggota kelompok mengubah motivasi atau kompetensi anggota lainnya di dalam kelompok".

Banyak lagi definisi tentang kepemimpinan, sama seprti banyaknya orang yang membuat definisi itu. Ada tiga implikasi penting yang tercakup dalam kepemimpinan dari beberapa definisi di atas yaitu: Pertama, kepemimpinan melibatkan orang lain, seperti bawahan atau para pengikut. Seorang wirausaha akan berhasil apabila dia berhasil memimpin karyawannya atau pembantu-pembantu yang mau bekerjasama dengan dia untuk memajukan perusahaan. Jadi wirausaha harus pandai merangkul dan melibatkan para karyawan dalam segala aktivitas perusahaan. Untuk melibatkan para karyawan, kemungkinan pemimpin harus menggunakan berbagai cara misalnya memberi hadiah, memberi nasehat, memberi imbalan yanng cukup kepada karyawan, dan sebagainya. Kedua, kepemimpinan menyangkut pembagian 
kekuasaan. Para wirausaha mempunyai otoritas untuk memberikan sebagian kekuasaan kepada karyawan atau seorang karyawan yang diangkat menjadi pemimpin pada bagian-bagian tertentu. Dalam hal ini seorang wirausaha telah membagikan kekuasaannya kepada karyawan lain untuk bertindak atas nama dia. Selanjutnya segala macam informasi sebagai hasil dari pengawasan dan pelaksanaan pekerjaan dapat dimonitor oleh pimpinan. Ketiga, kepemimpinan menyangkut penanaman pengaruh dalam rangka mengarahkan para bawahan. Seorang wirausaha tidak hanya mengingatkan apa yang harus dikerjakan oleh karyawan tetapi juga harus mampu memajukan perusahaan. Seorang wirausaha juga harus dapat memberi contoh yang baik, bagaimana melaksanakan pekerjaan sesuai dengan yanng diperintahkan.

Kepemimpinan kepala sekolah dalam penelitian ini merupakan kemampuan dari seorang kepala sekolah dalam mempengaruhi dan menggerakkan bawahan dalam suatu organisasi atau lembaga sekolah guna tercapainya tujuan sekolah. Terdapat empat macam pendekatan studi kepemimpinan, yaitu: (1) pendekatan pengaruh kewibawaan, (2) pendekatan sifat, (3) pendekatan perilaku, dan (4) pendekatan situasional. Fungsi dari kepemimpinan secara garis besar yaitu mempengaruhi dan menggerakkan orang lain dalam suatu organisasi agar mau melakukan apa yang dikehendaki seorang pemimpin guna tercapainya tujuan. Sedangkan syarat seorang pemimpin yaitu harus memiliki kemampuan dasar berupa technical skills, human skil, dan conceptual skill, serta pengetahuan dan keterampilan profesional. Dengan terpenuhinya syarat sebagai seorang pemimpin, maka seorang kepala sekolah dituntut untuk dapat memberi keteladanan dalam pelaksanaan tugas, menyusun administrasi dan program sekolah, menentukan anggaran belanja sekolah, dan pembagian pelaksanaan tugas. Sementara itu empat pola perilaku kepemimpinan yang lazim disebut gaya kepemimpinan meliputi perilaku instruktif, konsultatif, partisipatif, dan delegatif.

Sears, Freedman, \& Peplau (1992) sikap adalah keadaan mental dan syaraf dari kesiapan, yang diatur melalui pengalamanyang memberikan pengaruh dinamik atau terarah terhadap respon individu pada semua obyek dan situasi yang berkaitan dengannya.

David, Crutchfield, \& Ballachey (1962 :137139) sikap merupakan masalah pokok dalam psikologi sosial. Setiap kegiatan sosial kemanusiaan, siatur oleh sikap manusia itu sendiri. Dengan demikian sikap merupakaan kecendrungan penilaian positif atau negatif, perasaan emosional dan kecendrungan pro dan kontra terhadap objek sosial. Sikap mencerminkan tingkah laku sosial individu. Dengan demikian, sikap dapat digambarkan sebagai kecenderungan subyek merespon suka atau tidak suka terhadap suatu obyek. Dalam bahasan ini yang berperan sebagai subyek yaitu guru dan obyek yaitu pekerjaan yang diemban para guru.

Memperhatikan uraian tersebut di atas, Morgan, (1986: 328) mengatakan dapat dipahami bahwa sikap merupakan suatu bentuk evaluasi atau reaksi perasaan terhadap suatu obyek. Seseorang bersikap terhadap suatu obyek dapat diketahui dari evaluasi perasaannya terhadap obyek tersebut. Evaluasi perasaan ini dapat 
berupa perasaan senang-tidak senang, memihak tidak memihak, favorit-tidak favorit, dan positifnegatif.

Sikap guru terhadap pekerjaan merupakan keyakinan seorang guru mengenai pekerjaan yang diembannya, yang disertai adanya perasaan tertentu, dan memberikan dasar kepada guru tersebut untuk membuat respons atau berperilaku dalam cara tertentu sesuai pilihannya. Sikap guru terhadap pekerjaan mempengaruhi tindakan guru tersebut dalam menjalankan aktivitas kerjanya. Bilamana seorang guru memiliki sikap positif terhadap pekerjaannya, maka guru tersebut akan menjalankan fungsi dan kedudukannya sebagai tenaga pengajar dengan penuh rasa tanggung jawab.

Demikian pula sebaliknya seorang guru yang memiliki sikap negatif terhadap pekerjaannya, pastilah dia hanya menjalankan fungsi dan kedudukannya sebatas rutinitas belaka. Untuk itu, amatlah perlu kiranya ditanamkan sikap positif dan profesionalisme guru terhadap pekerjaan, mengingat peran guru dalam lingkungan pendidikan.

Sikap guru terhadap pekerjaan dapat dilihat dalam bentuk persepsi dan kepuasaannya terhadap pekerjaan maupun dalam bentuk motivasi kerja yang ditampilkan. Guru yang memiliki sikap positif terhadap pekerjaan, sudah barang tentu akan menampilkan persepsi dan kepuasan yang baik terhadap pekerjaannya maupun motivasi kerja yang tinggi, yang pada akhirnya akan mencerminkan seorang guru yang mampu bekerja secara profesional dan memiliki kompetensi profesionalisme yang tinggi.

Kecenderungan tersebut berpengaruh terhadap situasi guru di sekolah. Jamaluddin (dalam Sonedi, 2011) hasil penelitiannya mengungkapkan bahwa komitmen dan loyalitas guru terhadap pekerjaannya melaksanakan tugas mengajar sangat dipengaruhi oleh kepemimpinan kepala sekolah. Kepala sekolah memiliki peran yang kuat dalam mengkoordinasi, menggerakkan, dan menyerasi kegiatan pembelajaran. Sedangkan kepemimpinan kepala sekolah secara signifikan berpengaruh terhadap prestasi belajar peserta didik.

Hipotesis dalam penelitian ini adalah sebagai berikut : 1) ada hubungan kepemimpinan kepala sekolah dengan kompetensi profesional guru di SMP Negeri Kota Palangka Raya; 2) ada hubungan sikap guru terhadap pekerjaan dengan kompetensi profesional guru di SMP Negeri Kota Palangka Raya; 3) ada hubungan kepemimpinan kepala sekolah dan sikap guru terhadap pekerjaan dengan kompetensi profesional guru di SMP Negeri Kota Palangka Raya.

\section{METODOLOGI}

Metode penelitian yang digunakan dalam penelitian ini adalah metode survei. Penelitian ini bersifat korelasional karena penelitian berusaha mendeskripsikan hubungan antara beberapa variabel penelitian yaitu variabel kepemimpinan kepala sekolah dan sikap guru terhadap pekerjaan sebagai variabel bebas dan kompetensi professional guru sebagai variabel terikat.

Populasi target dalam penelitian ini, seluruh SMP Negeri yang ada di Kota Palangka Raya. Populasi sasaran hanya 10 SMP Negeri, dengan jumlah guru 50 orang. Semua populasi diambil sebagai sampel penelitian, karena jumlah jumlah populasi tidak mencapai 100 orang atau disebut juga dengan penelitian populasi. 
Teknik pengumpulan data tentang kepemimpinan kepala sekolah dan sikap guru terhadap pekerjaan menggunakan metode kuesioner dengan Skala Likert. Sedangkan pada kompetensi profesional guru menggunakan metode tes berupa tes kompetensi. Selanjutnya kuesioner dan soal tes diujikan kepada para guru yang menjadi sampel penelitian yang berjumlah 50 orang.

Teknik analisis data dilakukan melalui tiga tahapan, yaitu tahap deskripsi data, tahap uji persyaratan analisis, dan tahap pengujian hipotesis. Analisis data berdasarkan tiga tahapan tersebut dibantu dengan program SPSS for Windows.

\section{HASIL DAN PEMBAHASAN}

Pengujian hipotesis dilakukan guna mengetahui apakah hipotesis yang diungkapkan dalam penelitian ini dapat diterima atau ditolak. Berdasarkan hasil uji persyaratan ternyata pengujian hipotesis dapat dilakukan sebab sejumlah persyaratan yang ditentukan untuk pengujian hipotesis, seperti normalitas dan homogenitas dari data yang diperoleh telah dapat dipenuhi.

Hipotesis pertama menyatakah bahwa: ada hubungan positif kepemimpinan kepala sekolah dengan kompetensi profesional guru ekonomi di SMP Negeri Kota Palangka Raya.Untuk mengetahui hubungan kedua variabel tersebut, maka teknik analisisnya menggunakan analisis korelasi product moment. Berdasarkan hasil analisis data dengan menggunakan perhitungan SPSS 20.0 for windows, yaitu diperoleh nilai koefisinsi korelasi sebesar 0,498 dengan taraf signifikansi 0,000 pada tingkat kepercayaan 0,05.
Berdasarkan hasil perhitungan tersebut diperoleh nilai signifikansi sebesar 0,000 0,05 maka hipotesis penelitian diterima. Artinya ada hubungan positif yang signifikan antara kepemimpinan kepala sekolah dengan kompetensi professional guru ekonomi. Hubungan ini ditunjukan dengan nilai korelasi 0,498 termasuk dalam kategori sedang. Hasil perhitungan SPSS bisa dilihat dalam tabel 1.

Hipotesis kedua menyatakah bahwa: ada hubungan positif sikap guru terhadap pekerjaan dengan kompetensi profesional guru ekonomi di SMP Negeri Kota Palangka Raya. Berdasarkan hasil analisis data dengan menggunakan perhitungan SPSS 20.0 for windows, yaitu diperoleh nilai koefisinsi korelasi sebesar 0,571 dengan taraf signifikansi 0,000 pada tingkat kepercayaan 0,05.

Berdasarkan hasil perhitungan tersebut diperoleh nilai signifikansi sebesar $0,000<0,05$ maka hipotesis penelitian diterima. Artinya ada hubungan positif yang signifikan antara sikap guru terhadap pekerjaan dengan kompetensi profesional guru ekonomi. Hubungan ini ditunjukan dengan nilai korelasi 0,571 termasuk kategori sedang. Hasil perhitungan SPSS nya bisa dilihat dalam tabel 2.

Hipotesis ketiga menyatakah bahwa: ada hubungan positif kepemimpinan kepala sekolah dan sikap guru terhadap pekerjaan dengan kompetensi profesional guru ekonomi di SMP Negeri Kota Palangka Raya. Berdasarkan hasil analisis data dengan menggunakan perhitungan SPSS 20.0 for windows, yaitu diperoleh nilai koefisinsi korelasi sebesar 0,487 dengan taraf signifikansi 0,000 pada tingkat kepercayaan 0,05. 
Tabel 1. Uji hipotesis korelasi

\begin{tabular}{llcc}
\hline & Kepemimpinan & $\begin{array}{c}\text { Kompetensi } \\
\text { Kepala Sekolah }\end{array}$ & $\begin{array}{c}\text { Komesional Guru } \\
\text { Profes }\end{array}$ \\
\hline $\begin{array}{l}\text { Kepemiminan_Kepala_ } \\
\text { Sekolah }\end{array}$ & Pearson Correlation & 1 & $.498^{* *}$ \\
& Sig. (2-tailed) & & .000 \\
& $\mathrm{~N}$ & 50 & 50 \\
\hline Kompetensi_Profesional & Pearson Correlation & $.498^{* *}$ & 1 \\
Guru & Sig. (2-tailed) & .000 & \\
& $\mathrm{~N}$ & 50 & 50 \\
\hline
\end{tabular}

${ }^{* *}$. Correlation is significant at the 0.01 level (2-tailed)

Tabel 2. Uji hipotesis korelasi

\begin{tabular}{llcc}
\hline & Kepemimpinan & $\begin{array}{c}\text { Kompetensi } \\
\text { Kepala Sekolah }\end{array}$ & $\begin{array}{c}\text { Komosional Guru } \\
\text { Profesion }\end{array}$ \\
\hline $\begin{array}{l}\text { Sikap Guru Terhadap } \\
\text { Pekerjaan }\end{array}$ & Pearson Correlation & 1 & $.571^{* *}$ \\
& Sig. (2-tailed) & 50 & .000 \\
& $\mathrm{~N}$ & $.571^{* *}$ & 50 \\
\hline Kompetensi_Profesional & Pearson Correlation & .000 & 1 \\
_Guru & Sig. (2-tailed) & 50 & 50 \\
& $\mathrm{~N}$ & & \\
\hline
\end{tabular}

**. Correlation is significant at the 0.01 level (2-tailed)

Berdasarkan hasil perhitungan tersebut diperoleh nilai signifikansi sebesar $0,000<0,05$ maka hipotesis penelitian diterima. Artinya ada hubungan positif yang signifikan antara kepemipinan kepala sekolah dan sikap guru terhadap pekerjaan dengan kompetensi profesional guru. Hubungan ini ditunjukan dengan nilai korelasi 0,487 termasuk dalam kategori sedang.

Berdasarkan hasil penelitian di atas yang diuji dengan menggunakan teknik analisis korelasi Product Moment, menunjukan bahwa ada hubungan kepemimpinan kepala sekolah, sikap guru terhadap pekerjaan dengan kompetensi professional guru. Artinya bahwasemua hipotesis penelitian diterima. Hal tersebut sejalan dengan pendapat R.M. Imam I. Tunggara (2001), dalam penelitiannya bahwa perhatian guru dalam kegiatan yang dilakukan oleh kepala sekolah umumnya sama, hanya yang menjadi perhatian guru adalah kegiatan kepala sekolah. Kecenderungan tersebut berpengaruh terhadap situasi guru di sekolah. Pendapat Rosilawati (2001) dalam penelitiannya menyatakan bahwa dalam upaya mewujudkan sekolah efektif, di samping kreativitas pendidikan dari guru, murid, dan pihak-pihak yang berkepentingan terhadap pendidikan, ternyata berbagai keterampilan yang dimiliki kepala sekolah mempunyai peranan yang sangat penting, baik dalam memberdayakan sumber daya yang ada maupun mencari sumber yang belum tersedia.

Shum dan Cheng (1997) meneliti mengenai pengaruh kepemimpinan kepala sekolah wanita terhadap sikap kerja para guru di 77 sekolah yang 
dipimpin oleh kepala sekolah wanita dengan 321 para guru sebagai responden. Hasil penelitiannya mengungkapkan bahwa kepemimpinan kepala sekolah berpengaruh signifikan terhadap tanggungjawab para guru, rasa kebersamaan dalam komunitas, dan perhatian pada profesionalisme guru, dinyatakan bahwa persepsi positif dari dimensi kepemimpinan kepala sekolah.

Selain itu menempatkan kinerja sebagai landasan utama, membangun jaringan dari berbagai tipe manusia yang berlainan, mendorong pengembangan profesionalisme serta peningkatan pembelajaran melalui dimensi pengetahuan dan informasi.

Organisasi sekolah yang efektif akan selalu memprioritaskan terpeliharanya komunitas profesional (professional community) yang mengedepankan nilai-nilai kebersamaan, demokrasi dan hubungan dialogis. Kruse, Louis, dan Bryk, (1995) dan Louis, dan Marks (1996) menilai masyarakat profesional sebagai cikal bakal terwujudnya pembelajaran yang efektif di sekolah. Ciri utama masyarakat ini adalah tanggungjawab kolektif terhadap aktifitas belajar semua siswa untuk mencapai mutu dan tujuan pendidikan. Lebih lanjut, Marks dan Louis (1997) dalam penelitiannya mengidentifikasi masyarakat tersebut ke dalam lima ciri utama yaitu norma dan nilai bersama, fokus terhadap belajar siswa, aktivitas kolektif, de-privatisasi praktik, dan dialog reflektif.

E. Mulyana (2000), memberikan kesimpulan mengenai pengaruh gaya kepemimpinan yang kutip dari hasil penelitian Sutermeister (1980), bahwa ada beberapa faktor determinan terhadap produktivitas kerja antara lain: iklim kepemimpinan (leadership climate), tipe kepemimpinan (type of leadership) dan pemimpin (leader), dari 33 faktor lain yang berpengaruh. Lebih lanjut dikemukakan enam faktor yang turut menentukan tingkat produktivitas,yaitu: pendidikan, teknologi, tata nilai, iklim kerja, derajat kesehatan, dan tingkat upah minimal. Keenam faktor tersebut mengandung produktivitas tenaga kerja. Kesimpulannya adalah: bahwa gaya kepemimpinan berpengaruh terhadap kinerja pegawai untuk meningkatkan produktivitas kerja dalam mencapai tujuan.

Penelitian Hinde seperti yang dikutip Elliot, dkk, (1996) membuktikan bahwa perilaku dan prestasi siswa dipengaruhi oleh pendidik/guru. Guru yang bersikap positif cendrung memiliki siswa yang berprestasi tinggi dan memiliki keterampilan positif dalam mengerjakan tugas. Adanya hubungan tersebut didukung oleh Joni (1991) mengemukakan bahwa salah satu persyaratan penting bagi terwujudnya pendidikan yang bermutu adalah apabila pelaksanaannya dilakukan oleh guru-guru yang profesional.

Meter (2003) dalam hasil penelitian mengungkapkan bahwa ada hubungan antara perilaku kepemimpinan dalam hal ini kelapa sekolah dengan profesionalisme guru. Ini berarti, semakin baik perilaku kepala sekolah akan semakin tinggi tingkat prifesionalime guru. Selanjutnya Pidarta (2014) menemukan bahwa kepala sekolah yang memiliki kompetensi dan perilaku baik yang menberikan kesempatan untuk mengadakan diskusi-diskusi kelompok bidang studi akan bisa meningkatkan profesionalisme guru. Lebih lanjut Duke (1991) mengungkapkan bahwa kepala sekolah yang memberikan peranperan tertentu kepada guru akan dapat meningkatkan profesionalisme guru. 
Berdasarkan pendapat di atas, hasil penelitian ini sangat mendukung dan teruji bahwa kepemimpinan kepala sekolah secara signifikan memiliki hubungan dengan kompetensi professional guru. Begitu juga dengan sikap guru terhadap pekerjaan dengan kompetensi professional guru, memperkuat teori dan hasil penelitian terdahulu walaupun berdasarkan hasil penelitian hubungan antar variabel ada pada kategori sedang.

\section{KESIMPULAN DAN SARAN}

\section{Simpulan}

Berdasarkan hasil penelitian dapat disimpulkan:

a. ada hubungan yang signifikan kepemimpinan kepala sekolah dengan kompetensi profesional guru ekonomi di SMP Negeri Kota Palangka Raya. Hal ini berarti bahwa semakin tinggi tingkat kepemimpinan kepala sekolah, maka akan diikuti semakin tinggi pula kompetensi professional guru. Sebaliknya semakin rendah kepemimpinan kepala sekolah, akan semakin rendah pula kompetensi profesiona guru;

b. ada hubungan yang signifikan sikap guru terhadap pekerjaan dengan kompetensi professional guru ekonomi di SMP Negeri Kota Palangka Raya. Hal ini berarti bahwa semakin tinggi sikap positif guru terhadap pekerjaan, akan semakin tinggi pula komptensi professional guru, demikian juga sebaliknya;

c. ada hubungan yang signifikan kepemimpinan kepala sekolah dan sikap guru terhadap pekerjaan dengan kompetensi professional guru ekonomi di SMP Negeri Kota Palangka Raya.

\section{Saran}

Berdasarkan kesimpulan maka dapat disarankan beberapa hal sebagai berikut:

a. bagi kepala sekolah, agar dapat meningkatkan kualitas kepemimpinan sehingga memiliki kapasitas yang memadai sehingga mampu mempengaruhi dan menggerakkan para guru guna meningkatkan sikap positif terhadap pekerjaan untuk meningkatkan kompetensi professional guru mencapai mutu pendidikan yang lebih baik;

b. bagi guru hasil penelitian ini diharapkan pengetahuan dan dapat mengurangi sikap negatif terhadap pekerjaan. Hal ini dapat dilakukan dengan menjalankan fungsi dan kedudukannya sebagai tenaga pengajar dan pendidik di sekolah dengan penuh rasa tanggung jawab, memiliki kemandirian dalam peningkatan profesionalisme dan perlu meningkatkan pemahaman tentang prosedur kelas dalam melaksanakan pembelajaran di kelas.

\section{DAFTAR PUSTAKA}

Aqib, Zainal. 2013. Profesionalisme Guru Dalam Pembelajaran. Surabaya: Insan Cendekia.

David, K.,Crutchfield, R.S., \& Ballachey, E.L. 1962. Individual and Society. Tokyo: McGraw Hill, Kagakusha Ltd.

Djamarah, Syaiful B. 2012. Psikologi Belajar. Jakarta: Rineka Cipta.

Duke, D.L., \& Corno, L. 1991. Kepemimpinan Kepala Sekolah Dalam Rangka Meningkatkan Mutu Pengajaran. Surabaya: Laboratorium Administrasi Pendidikan FIP IKIP Surabaya. 
Elliot, S.N., Kretochwill, T.R., Liitlefield, J., \& Travers, J.F. 1996. Educational Psychology: Effective Teacher and Effective Learning. Dusuque: Brown \& Benchmark.

Ibrahim, R. 2012. Kurikulum Pembelajaran. Bandung: Jurusan Kurikulum dan Teknologi Pendidikan FIB UPI

Joni, T.R. 1991. Pokok-pokok Pikiran Mengenai Pendidikan Guru, Mencari Strategi Pembangunan Nasional Menjelang Abad XXI. Jakarta: PT. Grasindo.

Karsidi, R. 2005. Profesionalisme Guru dan Peningkatan Mutu Pendidikan di Era Otonomi Daerah. Makalah. Disampaikan dalam Seminar Nasional Pendidikan Dewan Pendidikan Kabupaten Wonogiri, 23 Juli 2005.

Kenezevich, S.J. 1984. Administration of Public Education. New York: Harper Collins Publisher.

Kruse, S.D., Louis, K.S., \& Bryk, A.S. 1995. An Emerging Framework for Analyzing SchoolBased Professionalism and Community. Thousands Oaks, CA: Corwin.

Lipham, J.M., Rankin, R.E., \& Hoeh, J.A., Jr. 1985. The Principalship: Concepts, Competencies, and Cases. New York: Logman, Inc.

Litrell, J.J. 1984. From School to Work. A Cooperative Education Book. South Holland, Illinois: The Goodheart Willcox Campany, Inc.

Louis, K.S., \& Marks, H.M. 1996. Does Professional Community Efect the Classroom? Teachers' Work and Studens Experiences in Restructuring School. Madison, WI: Center on Organization and Restructuring of School, University of Wisconsin.

Meter, I.G. 2003. Hubungan Antara Perilaku Kepemimpinan, Iklim Sekolah, dan Profesionalisme Guru dengan Motivasi Kerja Guru pada Sekolah Menengah Umum Negeri di Propinsi Bali. Disertasi tidak diterbitkan. Malang: PPs Universitas Negeri Malang.

Morgan, Clifford T. et. al. 1986 Introduction to Psychology. New York: McGraw-Hill.

Pidarta, M. 2014. Peran Kepala Sekolah pada Pendidikan Dasar. Jakarta: PT. Gramedia Widiasarana Indonesia.

R.M. Imam, I. Tunggara. 2001. Peranan Kepala Sekolah dalam Upaya Peningkatan Mutu Pendidikan Melalui Konsep Manajemen Berbasis Sekolah (Studi Kasus pada SLTP Swasta Kota Bandung), Tesis, Bandung: Program Studi Administrasi Pendidikan, Program Pasca Sarjana Universitas Pendidikan Indonesia, h. 141.

Rosilawati. 2001. Pemberdayaan Kemampuan Profesional Kepala Sekolah dalam Mengelola Pendidikan untuk Mewujudkan Sekolah Efektif (Studi Evaluatif pada SDN di Lingkungan Cabang Dinas $P$ \& $K$ Kecamatan Sukasari Kota Bandung), Tesis, Bandung: Program Studi Administrasi Pendidikan (S2), Program Pasca Sarjana Universitas Pendidikan Indonesia

Sears, D.O., Freedman, J.L., \& Peplau, L.A. 1992. Psikologi Sosial. Jakarta: Erlangga.

Shun, L.C., \& Cheng, Y.C. 1997. Perception Among Women Principals' Leadership and Teachers' Work Attitudes. Journal of Educational Administration. 35 (2): 165 184.

Sonedi. 2011. Hubungan Komptensi Kepala Sekolah, Sikap Guru Terhadap Pekerjaan, Profesionalisme Guru, dan Kinerja Guru dengan Mutu Lulusan pada SMP Negeri di Kabupaten kotawaringin Timur. Disertasi, Malang: PPs Program Studi Manajemen Pendidikan, Universitas Negeri Malang. Tidak dipublikasikan

Stoner, Jamer A.F. and Sindoro A. 1996. Manajemen. Jakarta: Prenhallindo.

Sudjana, Nana. 1989. Dasar-Dasar Proses Belajar Mengajar. Bandung: Sinar Baru. 
Undang-undang Nomor 14 Tahun 2005 tentang Guru dan Dosen. Jakarta: Depdiknas

Wahjosumidjo. 2012. Kepemimpinan Kepala Sekolah, Tinjauan Teoritik dan Permasalahannya. Jakarta: PT Raja Grafindo Persada.

Yukl, Gary A.. 1981. Leadership In Organization. New York: Prentice-Hall Inc 